\title{
Comparison of Forwarder Productivity and Optimal Road Density in Thinning and Clearcutting of Pine Plantation in Southern Brazil
}

\author{
Jean Alberto Sampietro, Daiane Alves de Vargas, Franciny Lieny Souza, \\ Marcos Felipe Nicoletti, Marcelo Bonazza, Larissa Regina Topanotti
}

\begin{abstract}
The prescription of forest management determines the number of trees to be cut and, consequently, the harvested wood volume, which directly influences the forest operations dynamic. The objectives of this paper were (i) to analyze the effect of process factors on wood extraction performance with forwarder in first thinning and clearcutting of Pinus taeda L. plantations; and (ii) to economically determine the optimal road density to manage these plantations. Time and motion studies at the cycle element level were conducted to quantify and model the time consumption, productivity, and operational costs of the extraction. The optimal road density (ORD) for both operation types (OT) was determined based on the transport geometry model, considering the minimization of the sum of unitary costs with construction and maintenance of roads, loss of productive area, and wood extraction. The extraction distance (ED), slope (SL), average log volume $(L V)$, and OT had a significant effect on the time consumed in travels, and therefore, on productivity $\left(\mathrm{P}_{P M H}\right)$. In clearcutting, the average $\mathrm{P}_{P M H}$ was $12.17 \mathrm{~m}^{3}$ ob $\mathrm{PMH}_{0}^{-1}$, while, in thinning, it was $10.94 \mathrm{~m}^{3} \mathrm{ob} \mathrm{PMH}_{0}^{-1}$; however, as the ED increased, the difference of $\mathrm{P}_{P M H}$ and the cost of extraction between the operations decreased, which highlighted a greater effect of this factor on forwarder's work in clearcutting. For this reason, the ORD for clearcutting $\left(37.76 \mathrm{~m} \mathrm{ha}^{-1}\right)$ was higher than for thinning $\left(27.84 \mathrm{~m} \mathrm{ha}^{-1}\right)$. Therefore, we demonstrated in this study that the type of operation and forest management regime, as well as their interaction with process factors, affect the sizing of the number of roads per unit area, and also the costs of the forest activity.
\end{abstract}

Keywords: time and motion study, productivity and costs of wood extraction, optimal road density

\section{Introduction}

The implantation and management of planted pine forests is a consolidated activity in Brazil, but the management strategies adopted by verticalized companies are different from those used by independent producers. The first ones generally aim to produce the maximum volume per unit area with a homogeneous production, while the latter usually intend to diversify the production seeking to trade logs for different industrial purposes.
Thus, when the forest production goal is to diversify wood products, the pine forests in Brazil are managed in longer rotations, often until 30 years, with the execution of two to four previous thinnings to the final cut (Spathelf and Seling 2000, Dobner et al. 2013). On the other hand, when the intention is to produce the maximum volume per unit area, the forests are usually managed in shorter rotation often of 15-20 years, without thinnings, and they are mainly directed to pulpwood or energy wood (Scolforo and Maestri 1997, Dobner et al. 2013). 
Therefore, different management prescriptions influence the dynamics in forest operations, once it entails differences in the harvested number of trees and wood volume per unit area, types of assortments, etc. In this sense, management regimes with thinning show more complex and costly operational conditions, especially in initial interventions, where the remaining trees limit the machinery access and mobility inside the stand. Also, the smaller trees and avoidance to damage the remaining plants reduce the operational performance, which increases the harvesting costs in this situation (Spinelli 2004). Many times, due to such conditions, the harvesting costs, added to the logistics costs (roads and transportation), are higher than the revenue from the timber trade, making the forest operations economically unfeasible.

On the other hand, the work conditions in operations of clearcutting tend to allow a better operational performance and lower costs than thinning, because the access and mobility restrictions of the machinery are lower. Besides, the work is more systematized, and displacements are lower due to the greater harvested volume per unit area.

The variations in the prescribed management influence directly both the cut operations (felling and processing) and the wood extraction, which, in turn, is extremely relevant to determine the number of roads per unit area in terms of the characteristics and peculiarities of each method and type of machine (Zagonel et al. 2008). Therefore, the redesign of the forest road system is necessary since there is an increase in the use of more sophisticated and powerful machines with greater work capacity, to replace rudimentary methods and equipment in Brazil (Seixas and Batista 2014).

In conditions where the road density is higher than necessary, their costs of construction and maintenance will be higher as well, consequently reducing the productive area. On the other hand, the wood extraction costs tend to be lower due to the reduction of extraction distance. Therefore, by minimizing the summed expenses with extraction, roads, and loss of productive area, it is possible to economically ascertain the optimal

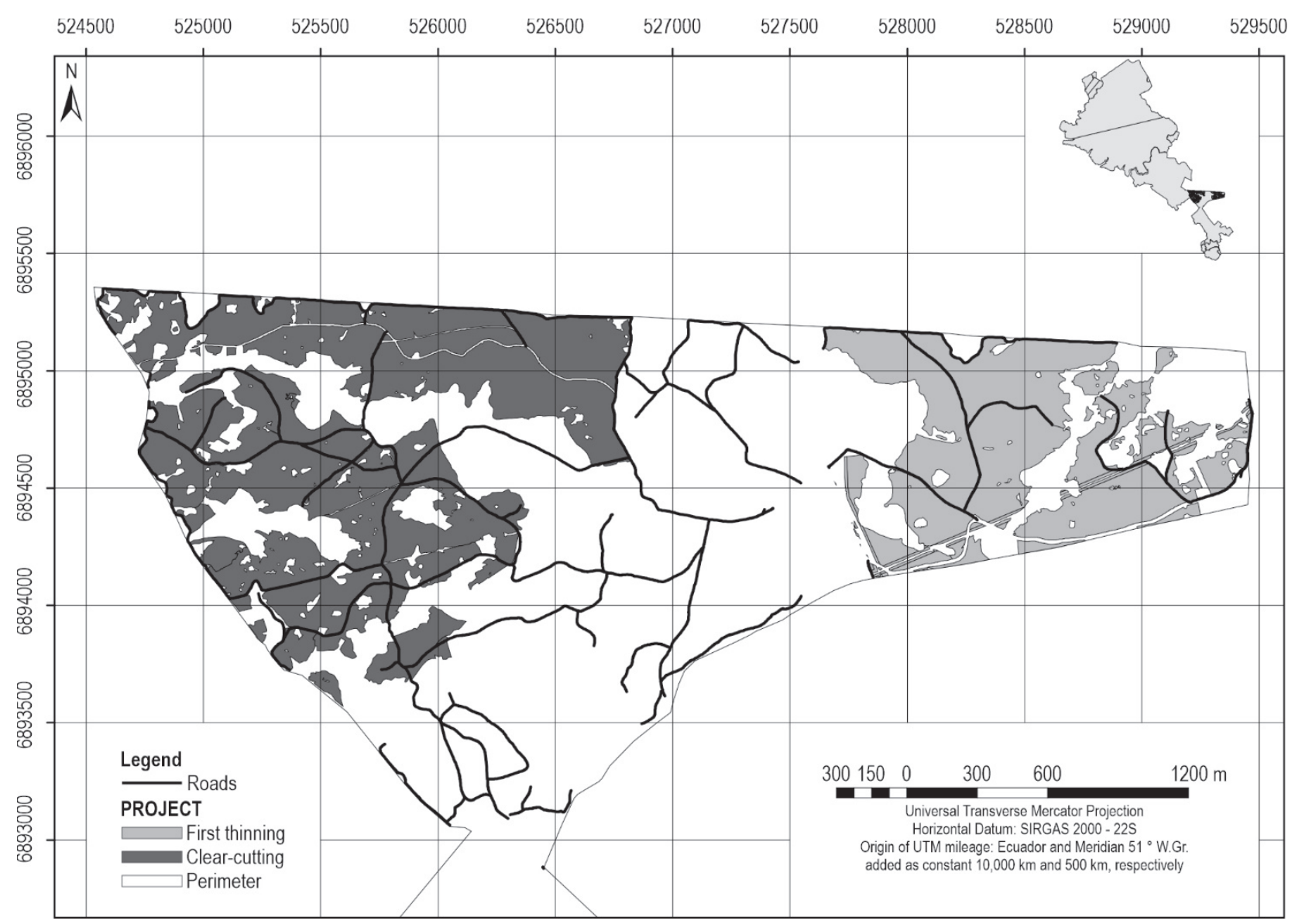

Fig. 1 Map of the project highlighting the areas where the first thinning (areas with a diagonal line, mostly on the right) and clearcutting (areas with dots, on the left) were performed on pine stands 
number of roads per unit area (Correa et al. 2006, Heinimann 2017).

Wood extraction cost depends on the operation productivity, which is influenced by several factors, mainly related to the forest off-road network efficiency, as stated by Zagonel et al. (2008), Naghdi and Limaei (2009), Ghaffarian et al. 2009, Hayati et al. (2012), Souza et al. (2018), and Toscani et al. (2020). Thus, developing predictive statistical models to estimate productivity is an alternative to quantify these relationships, and also to understand the influence of operational conditions and stand characteristics on forest work (Rodrigues et al. 2018, Hildt et al. 2020).

The objectives of this paper include the following: $\Rightarrow$ to analyze the effect of process factors on the operational performance of the wood extraction activity with forwarder in first thinning and clearcutting of pine planted forests

$\Rightarrow$ to determine the economical optimal density of secondary and tertiary roads for the pine plantation management under the conditions where the study was carried out.

\section{Materials and Methods}

\subsection{Study Area and Operational Conditions}

The study was carried out in a forest project with 89.9 ha of Pinus taeda L. stands belonging to a company located in the highlands of Santa Catarina State, Brazil. The relief is wavy to heavily wavy with an average slope of $13.35^{\circ}$. The average area of the stands was approximately $2.63 \mathrm{ha}$, and the average extraction distance was $121.76 \mathrm{~m}$ (Fig. 1).

The current road density (CRD), determined by the ratio between the total length of secondary and tertiary roads (in linear meters) and the effective planting area (in ha), was $45.28 \mathrm{~m} \mathrm{ha}^{-1}$. This value represents approximately $2 \%$ of the total project area, with a cor-
Table 1 Characteristics of stands analyzed in this study

\begin{tabular}{|c|c|c|}
\hline \multirow{2}{*}{ Stand characteristic } & \multicolumn{2}{|c|}{ Type of operation } \\
\hline & First thinning * & Clearcutting * \\
\hline Age, years & 11 & 10 \\
\hline Tree stocking, tree ha ${ }^{-1}$ & 1960 & 1920 \\
\hline Tree diameter breast height, $\mathrm{cm}$ & 18.7 & 19.2 \\
\hline Tree total height, $\mathrm{m}$ & 15.3 & 16.5 \\
\hline Basal area, $\mathrm{m}^{2} \mathrm{ha}^{-1}$ & 55.9 & 59.1 \\
\hline Tree individual volume, $\mathrm{m}^{3} \mathrm{ob}$ tree $\mathrm{e}^{-1}$ & 0.176 & 0.205 \\
\hline Volume harvested, $\mathrm{m}^{3} \mathrm{ob} \mathrm{ha}^{-1}$ & 141.0 & 393.6 \\
\hline
\end{tabular}

* Mean values

rection factor $(k)$ of 5.51 , which corresponds to hilly terrain according to FAO (1974).

Part of the project stands was subjected to first thinning, where approximately $20 \%$ of the trees were systematically harvested (cutting of trees in $5^{\text {th }}$ planting line), and another $30 \%$ were harvested by selective (crown) thinning. The remaining stands were submitted to clearcutting (Table 1). In both situations, three classes of log assortments were obtained, for pulp and sawmill; their average length and volume ranged be-

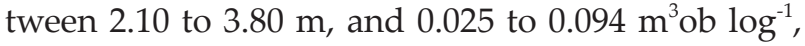
respectively.

The harvesting method in both situations was fully mechanized cut-to-length using the same machines. Tree felling and processing were performed by a John Deere 1270 harvester equipped with a Waratah H270 II head. Afterwards, the logs were extracted to the roadside by a John Deere 1510E forwarder, with the following characteristics: $145 \mathrm{~kW}$ power, tank capacity of 167 liters of fuel, 8WD traction, wheels covered by semi-tracks, and a $7.2 \mathrm{~m}$-reach hydraulic crane.

\subsection{Work Measurement of Wood Extraction}

Time and motion study data were collected at the cycle element level, following a modeling approach

Table 2 Forwarder working cycle elements

\begin{tabular}{|c|c|c|}
\hline Acronym & Element & Description * \\
\hline TE & Travel empty & Time consumed by the machine to leave the roadside landing area and start loading \\
\hline LD & Loading & Time consumed by the machine to load the logs \\
\hline TDL & Travel during loading & $\begin{array}{l}\text { Time consumed by the machine to move between loading stops. The loading stop is the working location } \\
\text { on the strip road where the loading element is carried out }\end{array}$ \\
\hline $\mathrm{TL}$ & Travel loaded & Time consumed by the loaded machine to move to the landing area and stop to begin unloading \\
\hline $\mathrm{MU}$ & Maneuver and unloading & $\begin{array}{c}\text { Time consumed by the forwarder to unload. It ends when the load is empty, and the machine is ready to } \\
\text { start the working cycle again }\end{array}$ \\
\hline
\end{tabular}

\footnotetext{
* Adapted from Laitila et al. (2007) and Norizah et al. (2016)
} 
(Magagnotti and Spinelli 2012, Ackerman et al. 2014). The forwarder effective working cycle was firstly divided into five elements (Table 2), and then the time spent in each element was measured by individual timekeeping methods using a centesimal stopwatch and specific forms.

In addition to time measurement, the production was obtained by counting the logs extracted at each working cycle (Magagnotti and Spinelli 2012). Thus, the volume produced in each working cycle in cubic meters of solid wood over bark $\left(\mathrm{m}^{3} \mathrm{ob}\right)$ was obtained, through the multiplication of the log number by the respective average volume by log according to the assortment. Previously, the diameter and length of 30 logs were measured for each assortment class produced during the study.

Data referring to the process factors were measured in each working cycle. The operation type (OT) corresponded to the first thinning or clearcutting. The operation direction (OD) represented the direction of movement related to the slope that the equipment performed when driving loaded, which could be uphill or downhill. The extraction distance (ED, in meters) was assessed with a TruPulse 360 Laser Rangefinder, and corresponded to the distance between the forwarder's longest stop to load logs and the first stop to unload logs on the roadside. The same device was also used to assess the land slope (LS, in degrees). The average log volume ( $\mathrm{LV}$, in $\left.\mathrm{m}^{3} \mathrm{ob} \mathrm{log}^{-1}\right)$ corresponded to the ratio of the total extracted volume in the cycle by the number of extracted logs in the respective cycle.

As a comparative study, we sought to standardize and control all the process factors related to the operational conditions, as proposed by Magagnotti and Spinelli (2012) and Ackerman et al. (2014). Although the forwarder has been operated by different operators during the study, their ability level was similar (intermediary/advanced) and did not result in differences related to this factor.

The specific time consumption by each cycle element was calculated in productive machine minutes (PMmin $\mathrm{m}^{-3} \mathrm{ob}$ ) by the ratio between the time consumed in the respective element and the volume produced in the respective cycle (Vcycle). The delay-free machine hour productivity $\left(P_{\mathrm{PMH}}, \mathrm{em} \mathrm{m}{ }^{3} \mathrm{ob} \mathrm{PMH}_{0}^{-1}\right)$ was calculated by the ratio between the Vcycle and the total time consumed in the working cycle (Tcycle). The productivity per scheduled machine-hour $\left(P_{\mathrm{SMH}}\right)$ resulted from the multiplication of the $P_{\mathrm{PMH}}$ by the utilization rate (TU) seen.

The data of time consumption in each cycle element and the productivity were analyzed by descrip- tive statistics and expressed by boxplots. The relative sampling errors for the variable $P_{\mathrm{PMH}}$ were determined for $5 \%$ significance $(p<0.05)$, according to Szewczyk et al. (2017).

To test the data normality, the KolmogorovSmirnov test was applied using 5\% significance $(p<0.05)$. In the case of non-normality, the values were mathematically transformed to fulfill this assumption. Then, the values were submitted to Pearson's correlation analysis $(r, p<0.05)$ to verify the relation between the variables of interest (time and productivity) with the process factors of quantitative random effects (ED, $\mathrm{SL}$, and LV).

The effect of the process factors on the specific time consumed in the working cycle and $P_{\mathrm{PMH}}$ were also assessed by the General Linear Model (GLM) and multiple linear regression by stepwise technique $(p<0.05)$. The quantitative factors ED, SL, and LV were considered as random effect variables, while the categoric factors OT and OD were the fixed effect variables. The equations fitting was assessed by the adjusted coefficient of determination (Adj. $\left.R^{2}\right)$, absolute $(S y x)$ and relative $(S y x \%)$ standard error of the estimate, and the $F$ value. All the analyses were performed on the software R (R Core Team 2019), using specific packages.

\subsection{Determination of Optimal Forest Road Density (ORD)}

Due to the specificity of use and construction of primary roads, the assessments performed in this study included only the secondary and tertiary forest roads network. While the secondary roads were coated with gravel, used intermittently, and had an average width of $5.5 \mathrm{~m}$, the tertiary roads were coated in specific points, used seasonally, and had an average width of $3.5 \mathrm{~m}$.

On this premise, the ORD for each type of operation was calculated based on the approaches adopted by Ryan et al. (2004), Zagonel et al. (2008), and Souza et al. (2018), who used the transport geometry model to relate the average extraction distance with the road density (FAO 1977, Ghaffarian et al. 2009, Heinimann, 2017).

The costs with road construction $(\mathrm{Cc})$ were calculated as the sum of depreciation and opportunity costs, considering a period of 11 and 10 years for the first thinning and clearcutting, respectively. Depreciation was not considered for the costs related to the road maintenance activities $(\mathrm{CM})$, as these occurred in that specific period.

The costs related to the loss of productive area (Cpap) corresponded to the value of the standing 
timber that would be produced, annually, in the area occupied by the roads, according to the management regime. In the first thinning, a management regime was considered where three thinnings would be conducted at 11, 15, and 20 years of age and clearcutting at 25 years, with an average production of 141, 160, 190, and $614 \mathrm{~m}^{3} \mathrm{ob} \mathrm{ha}^{-1}$ and an average price of the standing timber of $12.23,12.23,24.13$ and 54.34 US $\$ \mathrm{~m}^{-3} \mathrm{ob}$, respectively, for each intervention. For clearcutting, a 10-year rotation regime and an average production of $393.60 \mathrm{~m}^{3} \mathrm{ob} \mathrm{ha}{ }^{-1}$ was considered. The price of useful land for planting adopted for both operations was 1486.54 US\$ ha ${ }^{-1}$.

The operational costs with extraction were determined according to the methodology proposed by Miyata (1980), considering an annual use of $3366 \mathrm{PMH}_{0}$ (delay-free productive machine hour), and a depreciation period of 5.9 years. A TU of $75 \%$ was assumed,

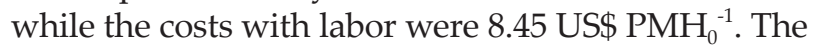
interest rate used was $4 \% \mathrm{yr}^{-1}$, and the cost of fuel was 0.92 US $\$ 1^{-1}$. Using the sum of operational costs, the extraction cost was calculated by the ratio between the total operational cost (in US\$ $\mathrm{PMH}_{0}^{-1}$ ) and the $P_{\mathrm{PMH}}$ (in $\left.\mathrm{m}^{3} \mathrm{ob} \mathrm{PMH}_{0}^{-1}\right)$. The effect of road network efficiency on the extraction cost was determined using the regression models that were fitted to estimate the operation productivity as a function of process factors.

Then, the ORD was determined as the density of roads including the minimization of the summed costs of road construction and maintenance, productive area loss, and wood extraction. All the data and rates used were obtained from the company or determined in the field, and they refer to the period of July/August of 2016 (US\$ 1.00=R \$ 3.27).

\section{Results}

A total of 24.8 and 22.9 productive machine hours were measured in the operation of first thinning and clearcutting, respectively (Table 3 ). Although the number of valid forwarding cycles has been greater in clearcutting $(n=42)$, the relative sampling error was higher in this type of operation $(10.63 \%)$ due to greater variation in the productivity values compared to the first thinning.

The clearcutting total average time consumption per cycle was lower $\left(5.60 \mathrm{PMmin}^{3} \mathrm{Ob}^{-1}\right)$ than thinning $\left(5.86 \mathrm{PMmin} \mathrm{m}^{3} \mathrm{ob}^{-1}\right)$, which, in turn, showed less average productivity, even with the extraction of a greater volume per cycle (6.32 vs. $6.26 \mathrm{~m}^{3} \mathrm{ob}_{\text {cycle }}{ }^{-1}$ ) (Table 3 ).

In both types of operation, most of the working cycle time was consumed by loading (LD) and unload-
Table 3 Summary of variables analyzed in the study

\begin{tabular}{|c|c|c|}
\hline Type of operation & First thinning & Clearcutting \\
\hline Study duration, shifts & 3.5 & 3.6 \\
\hline Duration of valid observations, $\mathrm{PMH}_{0}$ & 24.8 & 22.9 \\
\hline Proportion of time consumed in delays, $\%$ & 17.1 & 13.1 \\
\hline Total volume extracted in study, $\mathrm{m}^{3}$ & 259.13 & 265.14 \\
\hline ED - mean ( \pm SD), m & $136.2( \pm 82.6)$ & $175.4( \pm 102.6)$ \\
\hline $\mathrm{SL}-$ mean $( \pm \mathrm{SD})$, degree & $5.6( \pm 2.15)$ & $6.1( \pm 3.02)$ \\
\hline $\mathrm{LV}$ - mean $( \pm \mathrm{SD}), \mathrm{m}^{3} \mathrm{ob} \log ^{-1}$ & $0.03( \pm 0.014)$ & $0.03( \pm 0.018)$ \\
\hline $\mathrm{T}_{\text {cycle }}-$ mean $\left( \pm\right.$ SD), PMmin $\mathrm{m}^{3} \mathrm{ob}^{-1}$ & $5.86( \pm 1.51)$ & $5.60( \pm 2.27)$ \\
\hline $\mathrm{V}_{\text {cycle }}-$ mean $( \pm \mathrm{SD}), \mathrm{m}^{3} \mathrm{ob}$ cycle ${ }^{-1}$ & $6.32( \pm 1.43)$ & $6.26( \pm 2.25)$ \\
\hline 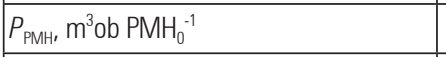 & $10.94( \pm 2.90)$ & $12.17( \pm 4.15)$ \\
\hline$P_{\text {SMH }}, \mathrm{m}^{3} \mathrm{ob} \mathrm{SMH}{ }^{-1}$ & $9.27( \pm 2.46)$ & $10.31( \pm 3.52)$ \\
\hline Number of valid observations, cycles & 41 & 42 \\
\hline Relative sampling error, \% & 8.14 & 10.63 \\
\hline
\end{tabular}

$\mathrm{PMH}_{0}$ - interruption-free productive machine hour productivity; SD - standard deviation; ED - Extraction distance; SL - slope; LV - log volume; $\mathrm{T}_{\text {cycle }}$ - total time consumption per working cycle; $V_{\text {cycle }}-$ Volume per cycle; $P_{\mathrm{PMH}}-$ Productivity per productive machine hour; $P_{\mathrm{SMH}}-$ Productivity per scheduled machine hour

ing (MU) elements (Fig. 2). In clearcutting, on average, more time was consumed by the elements of travel empty (TE), travel loaded (TL), and maneuver and unloading (MU), while in first thinning, more time was consumed by log loading (LD) and travel during loading (TDL).

The time consumed in each cycle element in both types of operation had, in general, normal statistical distribution (data not showed), except for the TDL element, which presented a high variation in first thinning (Fig. 2c). In this case, a logarithmic transformation was applied to show a normal distribution.

There was a significant and positive correlation among the specific time consumption of the cycle elements (Table 4) for all of them, except for the TDL element, which has not shown a significant correlation with TE and TL. These elements (TE and TL) only showed a positive correlation with the ED ( $r=0.50$ and 0.55 , respectively), while the TDL element was significant and positively correlated with SL and LV ( $r=0.30$ and 0.24 , respectively).

The productivity $\left(P_{\mathrm{PMH}}\right)$ showed a significant and negative correlation with the specific time consumption of all the working cycle elements, and the highest value of correlation coefficient was observed with the loading element $(r=-0.80)$. Regarding the random quantitative factors, the $P_{\mathrm{PMH}}$ showed a significant and negative correlation with $\mathrm{ED}(r=0.22)$ and SL $(r=0.25)$, and no correlation was detected with LV. 

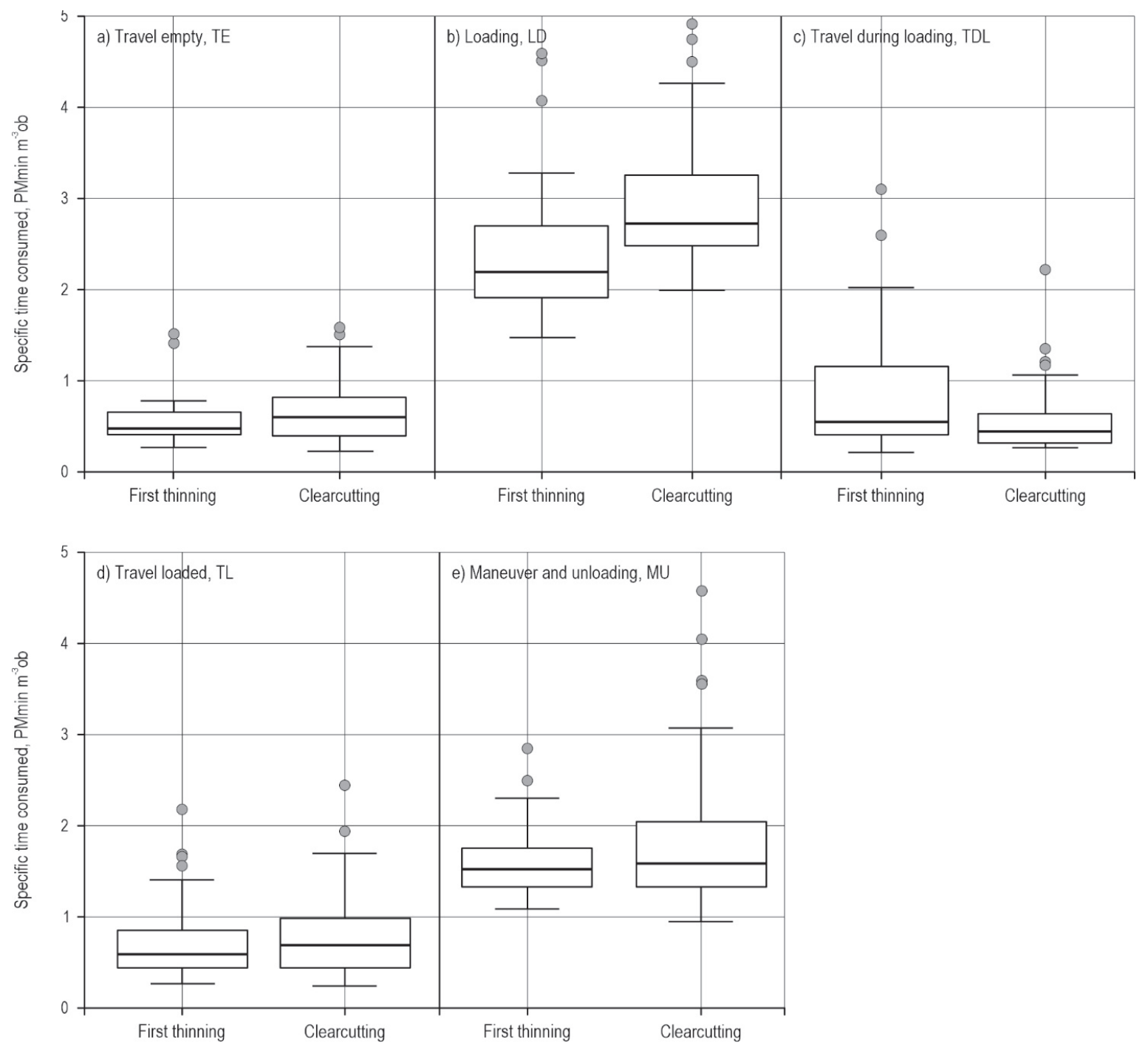

Fig. 2 Boxplot of cycle elements for wood extraction with forwarder in clearcutting and first thinning

Table 4 Matrix of Pearson's linear correlation coefficients among time consumed in working cycle elements, productivity, and process factors for Pinus taeda wood extraction with forwarder in first thinning and clearcutting

\begin{tabular}{|c|c|c|c|c|c|c|c|c|c|}
\hline \multicolumn{10}{|c|}{ Variables } \\
\hline & TE & LD & TDL & $\mathrm{TL}$ & $\mathrm{MU}$ & $P_{\mathrm{PMH}}$ & ED & SL & LV \\
\hline TE & - & - & - & - & - & - & - & - & - \\
\hline LD & $0.42^{* *}$ & - & - & - & - & - & - & - & - \\
\hline TDL & $0.00^{\text {ns }}$ & $0.55^{* *}$ & - & - & - & - & - & - & - \\
\hline TL & $0.59 * *$ & $0.47^{* *}$ & $0.06^{\text {ns }}$ & - & - & - & - & - & - \\
\hline MU & $0.49^{* *}$ & $0.60^{* *}$ & $0.27^{*}$ & $0.41^{* *}$ & - & - & - & - & - \\
\hline$P_{\mathrm{PMH}}$ & $-0.54^{* *}$ & $-0.80 * *$ & $-0.60^{* *}$ & $-0.61^{* *}$ & $-0.65^{* *}$ & - & - & - & - \\
\hline ED & $0.50^{* *}$ & $0.10^{\mathrm{ns}}$ & $-0.16^{\mathrm{ns}}$ & $0.55^{* *}$ & $0.05^{\text {ns }}$ & $-0.22^{*}$ & - & - & - \\
\hline$S L$ & $0.02^{\text {ns }}$ & $0.21^{\mathrm{ns}}$ & $0.30^{* *}$ & $0.11^{\text {ns }}$ & $-0.00^{\text {ns }}$ & $-0.25^{*}$ & $0.00^{\text {ns }}$ & - & - \\
\hline LV & $-0.01^{\mathrm{ns}}$ & $0.02^{\text {ns }}$ & $0.24^{*}$ & $-0.08^{\mathrm{ns}}$ & $-0.11^{\mathrm{ns}}$ & $-0.06^{\mathrm{ns}}$ & $0.06^{\text {ns }}$ & $-0.06^{\mathrm{ns}}$ & - \\
\hline
\end{tabular}

${ }^{* *}$ - significant at 1\%; ${ }^{*}$ - significant at 5\%; ns - not significant; TE - travel empty; LD - loading; TDL - travel during loading; TL - travel loaded; MU - maneuver and unloading; $P_{\mathrm{PMH}}-$ Productivity per productive machine hour; ED - extraction distance; SL - slope, LV - average log volume 
Table 5 Analysis of variance ( $F$ value and correspondent significance) obtained by General Linear Model of time consumed in operational cycle elements and productivity in wood extraction with forwarder

\begin{tabular}{|l|c|c|c|c|c|c|}
\hline & \multicolumn{5}{|c|}{ Dependent variables } \\
\hline $\begin{array}{l}\text { Variation } \\
\text { factor }\end{array}$ & TE & $L D$ & TDL & TL & MU & $P_{\text {PMH }}$ \\
\hline ED & $26.81^{* *}$ & $0.900^{\text {ns }}$ & $3.329^{\text {ns }}$ & $36.430^{* *}$ & $0.213^{\text {ns }}$ & $4.552^{*}$ \\
\hline SL & $0.043^{\text {ns }}$ & $3.635^{\text {ns }}$ & $10.935^{*}$ & $1.553^{\text {ns }}$ & $0.001^{\text {ns }}$ & $5.990^{*}$ \\
\hline $\mathrm{LV}$ & $0.054^{\text {ns }}$ & $0.087^{\text {ns }}$ & $9.689^{*}$ & $1.470^{\text {ns }}$ & $1.122^{\text {ns }}$ & $0.429^{\text {ns }}$ \\
\hline OD & $0.395^{\text {ns }}$ & $0.148^{\text {ns }}$ & $5.935^{*}$ & $0.343^{\text {ns }}$ & $0.427^{\text {ns }}$ & $0.405^{\text {ns }}$ \\
\hline OT & $2.092^{\text {ns }}$ & $1.811^{\text {ns }}$ & $19.971^{* *}$ & $0.393^{\text {ns }}$ & $2.539^{\text {ns }}$ & $5.124^{*}$ \\
\hline
\end{tabular}

${ }^{* *}$ - significant at $1 \% ;{ }^{*}$ - significant at $5 \%$; ns - not significant; TE - travel empty; LD - loading; TDL - travel during loading; TL - travel loaded; MU - maneuver and unloading; $P_{\mathrm{PMH}}$ - Productivity per productive machine hour; $\mathrm{ED}$ - Extraction distance; SL - slope; LV - average log volume; OD - operation direction; OT - operation type

The variance analysis by GLM revealed that there was a significant effect of ED on time consumed in TE and TDL and, consequently, on productivity (Table 5). The factors SL, LV, operation direction (OD), and operation type $(\mathrm{OT})$ had a significant effect on the specific time consumption in TDL; however, only SL and OT significantly affected the $P_{\mathrm{PMH}}$. None of the process factors showed a significant effect on time in LD and MU.

As the OT affected the $P_{\mathrm{PMH}}$, multiple linear regression equations were individually fitted for the productivity in first thinning and clearcutting (Table 6). In both regression equations, the variables ED and SL were entered as explanations of the $P_{\mathrm{PMH}}$ variation, but for thinning, there was also the participation of the variable LV. However, the equation for the clearcutting had a fitting slightly better than the one fitted for the first thinning, as it showed smaller Syx (\%), and higher $F$ value, although the Adj. $R^{2}$ was a little lower.

In both operations, there was a trend to decrease the $P_{\mathrm{PMH}}$ (Fig. 3a) and increase the cost of extraction (Fig. $3 \mathrm{~b}$ ) as the ED increased. In clearcutting, the productivity tended to be greater and the cost lower than in the first thinning, but such difference was smaller as the ED increased.
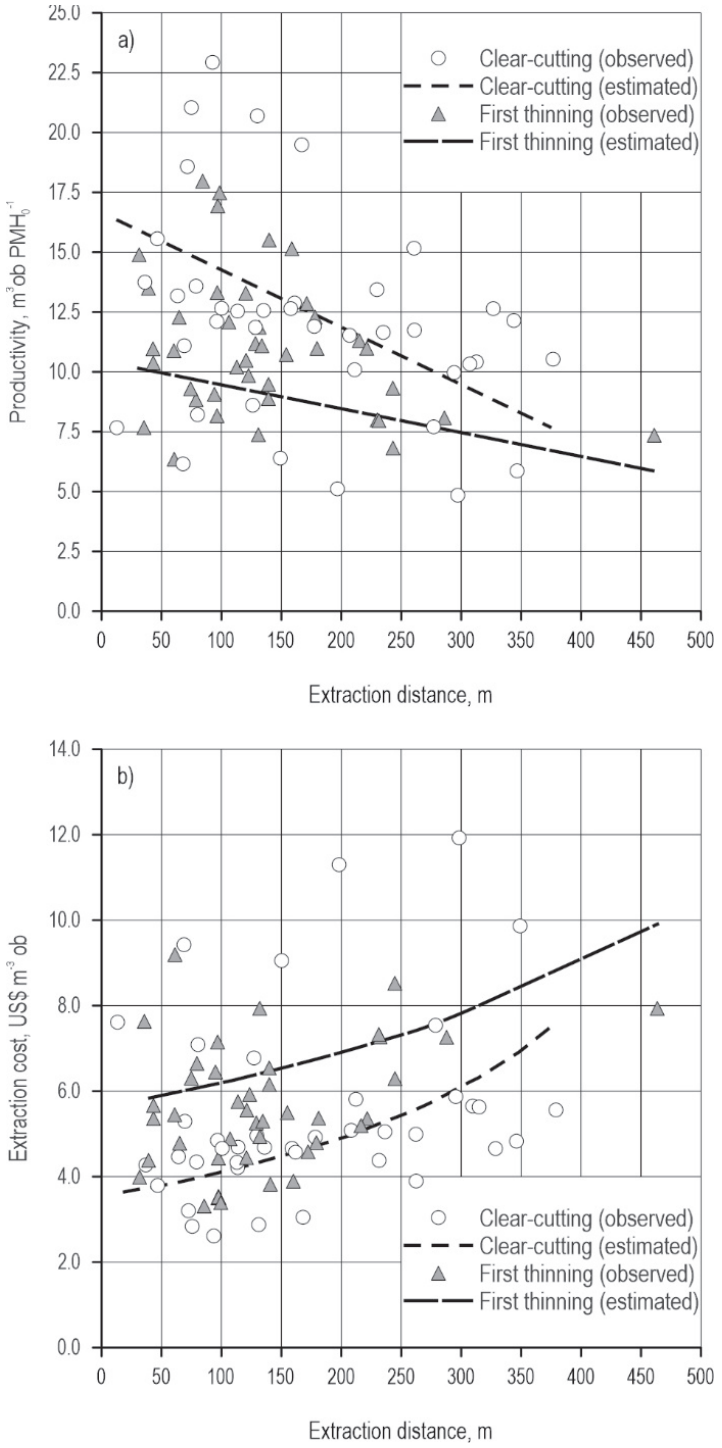

Fig. 3 Variation of forwarder productivity (a) and extraction cost (b) with extraction distance in first thinning and clearcutting in Pinus taeda stands. Mean observed values of SL and LV were used to estimate productivity

The economically optimal road density for first thinning $\left(\mathrm{ORD}=27.84 \mathrm{~m} \mathrm{ha}^{-1}\right)$ was lower compared to clearcutting $\left(\mathrm{ORD}=37.76 \mathrm{~m} \mathrm{ha}^{-1}\right)$ (Fig. 4) and both

Table 6 Fitting parameters of stepwise multiple linear regression equations to estimate productivity in wood extraction with forwarder in first thinning and clearcutting

\begin{tabular}{|c|c|c|c|c|c|}
\hline Operation & Fitted equation & $R^{2}$ adj & Syx & Syx,$\%$ & $F$ Value \\
\hline First thinning & $P_{\mathrm{PMH}}=19.95-0.010 \mathrm{ED}-2.44 \sqrt{\mathrm{SL}}-15.82 \mathrm{VLV}$ & 0.542 & 2.59 & 23.86 & $7.51^{* *}$ \\
\hline Clearcutting & $P_{\mathrm{PMH}}=18.99-0.024 \mathrm{ED}-0.04 \mathrm{SL}^{2}$ & 0.513 & 2.32 & 19.06 & $15.76^{* *}$ \\
\hline
\end{tabular}

${ }^{* *}$ - significant at 1\%; ${ }^{*}$ - significant at 5\%; ED - extraction distance in $\mathrm{m}$; SL - slope in degrees; LV - log volume in $\mathrm{m}^{3} \mathrm{ob} ; R^{2}$ adj - adjusted determination coefficient; Syx estimate standard error in $\mathrm{m}^{3} \mathrm{ob} \mathrm{PMH}_{0}{ }^{-1} ; \mathrm{Syx} \%$ - relative estimate standard error in \% 
were lower than the current road density (CRD) $\left(45.28 \mathrm{~m} \mathrm{ha}^{-1}\right)$.

In the first thinning, the total cost in ORD was 11.80 US\$ $\mathrm{m}^{-3} \mathrm{ob}$ (Fig. 4a), against a total cost of $12.57 \mathrm{US} \$ \mathrm{~m}^{-3} \mathrm{ob}$ in CRD, which represents a total reduction of $6.13 \%$. In an optimal scenario, the costs with construction and maintenance of roads and loss of productive area would be reduced by $38.51 \%$, while the extraction cost would increase by $11.70 \%$, as a result of the increase in average extraction distance (198 m).
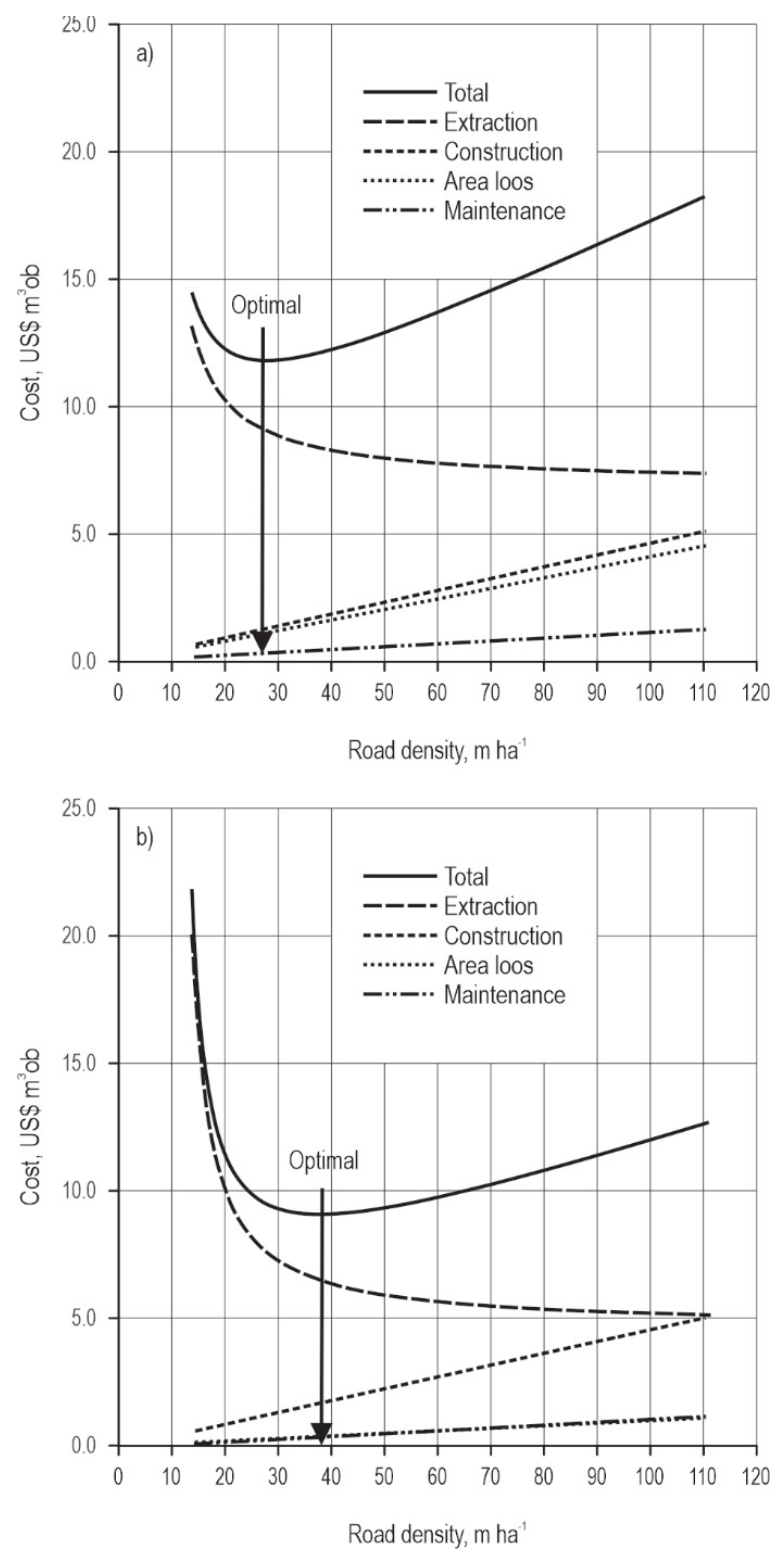

Fig. 4 Relation between road density and costs of road construction and maintenance, productive area loss, extraction, and total cost for first thinning (a) and clearcutting (b) operations in pine stands with forwarder in cut-to-length harvesting method
Comparatively, in clearcutting, the total reduction of costs would be smaller $(1.20 \%)$, since the total cost in ORD was $9.11 \mathrm{US} \$ \mathrm{~m}^{-3} \mathrm{ob}$ (Fig. 4b), against a total cost of 9.22 US $\$ \mathrm{~m}^{-3} \mathrm{ob}$ in CRD. In the optimization scenario, the reduction of costs with construction and maintenance of roads and loss of productive area would be $16.60 \%$, with a rise of $6.56 \%$ in the extraction cost and $146 \mathrm{~m}$ in the average extraction distance.

\section{Discussion}

The average specific time consumption by the elements TE and TL was slightly higher in clearcutting operation than in first thinning (Fig. 1a and 1d). However, there was no significant difference between these elements when comparing the operations (Table 5), as reported by Kuitto et al. (1994) and Nurminem et al. (2006).

These elements had a positive correlation (Table 4), and they were only dependent on the extraction distance (Table 5), which denotes a tendency to spend more time in these elements as the extraction distance increases, as supported by the results of Nurminem et al. (2006), Leite et al. (2014) and Strandgard et al. (2017). Both TE and TL depend on the forwarding distance and driving speed, which in turn are mainly affected by geophysical factors (Manner et al. 2013), such as microrelief, stoniness, and soil bearing conditions, which have not been measured in this study.

In both operations, the size of the loads was limited by the physical dimensions of the machine compartment, which did not allow its full occupation because the logs length restricted the loading to only two bundles per cycle. However, a variation in the size of the loads transported per cycle was observed (Table 3), which may have induced a hypothetical correlation between TE and TL elements, since it acts as a divisor to calculate each specific time consumed.

The LD element was the step that consumed most of the time in the whole forwarder working cycle (Fig. $2 b$ ) and presented the greatest value of correlation with productivity (Table 4 ). The positive correlation of this element with other cycle elements was due to the work procedure adopted by the operators, who sought to optimize the occupation of the machine load compartment in cycles with longer trips. These results agree with the findings of many authors that studied this machine in different operational conditions (Spinelli et al. 2004, Ghaffarian et al. 2012, Leite et al. 2014, Walsh and Strandgard 2014, Strandgard et al. 2017).

The average specific time consumption with the LD element was higher in thinning (Fig. 1b). However, 
it was not dependent on the type of operation (Table 5) and was not correlated with other process factors (Table 4). Studies, such as that of Strandgard et al. (2017), Holzfeind et al. (2018), and Hildt et al. (2020), showed that the extraction of logs with greater average volume consumed less time compared to logs with smaller volume since larger sized logs require fewer grapple movements to complete the load.

In this study, no effect of the LV was observed on the time consumed by LD. Although the logs for sawmill were larger than the logs designed for pulp (average volume of 0.080 and $0.031 \mathrm{~m}^{3} \mathrm{ob} \mathrm{log}^{-1}$, respectively), the concentration per unit area of these logs was lower than that of the smaller ones, which, in turn, corresponded to approximately $70 \%$ of the total volume produced in both operations. In the studies of Nurminen et al. (2006) and Manner et al. (2013), the assortments with a lower amount and concentration of logs per unit area led to more time consumption in loading because fewer logs were available in each stop for loading.

Besides, the time consumed in LD may also increase as the number of assortments extracted from the same load is larger, as reported by Nurminen et al. (2006) and Manner et al. (2013). In this study, it was noted that only one class of assortment was loaded in most of the valid cycles, and that is why such behavior was not verified.

The TDL was dependent on the type of operation (Table 5), and it showed more variability and average specific time consumption in the first thinning than in clearcutting (Fig. 2c). This tendency can be explained number of logs along the strip roads in thinning, which required a higher number of travels between log piles to complete the load in each work cycle, which corroborates with Nurminen et al. (2006), Stankić et al. (2012), Manner et al. (2013) and Hildt et al. (2020).

Therefore, the positive correlation and dependency between the specific time consumption in TDL and LV (Tables 4 and 5) was also a result of the number and concentration of logs in the strip roads. As the logs of a greater average volume represented around 30\% of the total volume produced, their piles were more sparse along the strip roads, which demanded more time by this element in the working cycle, even though, in this study, the concentration of logs in the strip roads such as in Strandgard et al. (2017) has not been determined.

Additionally, the time consumption in TDL had a positive correlation, and it was dependent on the SL (Tables 4 and 5). Leite et al. (2014) revealed that the steeper the terrain, the higher the work difficulty level is. Also, the authors affirmed that the log organization is more challenging after felling and processing by a harvester in steep areas, as some of them can roll over; this results in smaller and more sparse piles and, thus, requires more attention to the displacement among piles.

A significant effect of OD on TDL (Table 5) was also verified, which can be justified by a better log organization after cutting and greater flexibility of displacement among the uphill log piles, resulting in less time consumption.

The time consumption in MU was more variable in clearcutting than in thinning (Fig. 1e). However, the operation type and direction did not influence this working cycle element (Table 5), and there was no significant correlation with other process factors (Table 4). In the study of Hildt et al. (2020), the LV affected the time consumption by MU since the activity of unloading logs of smaller volumes was more time-consuming, as verified by Nurminen et al. (2006). However, in the case of this study, the difference in volume among the log assortment classes was inferior to the one reported in the studies mentioned above, which justifies the non-existence of correlation between MU and LV.

The greater the time consumption in the working cycle elements, the smaller the forwarder $P_{\mathrm{PMH}}$ was, which is confirmed by the correlation coefficient values (Table 4). In first thinning, although the average volume transported per cycle was greater than in clearcutting (Table 3), the total time consumption by work cycle was higher and, therefore, the $P_{\mathrm{PMH}}$ was lower, which emphasizes the significant effect of the operation type (Table 5).

This difference in performance occurred especially due to the lower concentration and number of logs throughout the strip roads in thinning. Besides, the remaining trees made difficult the movement of machines inside the stump area (Spinelli 2004, Malinovski et al. 2006, Manner et al. 2013), which was reflected in greater time consumption by TDL and, consequently, lower productivity.

In addition to the significant effect of OT, the $P_{\mathrm{PMH}}$ also showed a negative correlation (Table 4) and a dependence on the ED and SL factors (Table 5). Greater extraction distances resulted in more time consumed in travels (empty and loaded), while greater slopes increased the time of travels during loading, which resulted in productivity loss. Other studies verified the same fact, and some of them also modeled the productivity based on such relation (Tiernan et al. 2004, Walsh 
and Strandgard 2014, Leite et al. 2014, Lopes et al. 2016, Strandgard et al. 2017, Rodrigues et al. 2018, Hildt et al. 2020).

In clearcutting, the observed values of ED, SL, and LV had greater variability, which justifies the greater fluctuation and sampling error of the $P_{\mathrm{PMH}}$ for this type of operation (Table 3). However, only for the first thinning, the LV was entered as an additional explaining variable in the fitted equation (Table 6).

In contrast to the studies of Oliveira et al. (2009), Ghaffarian et al. (2012), Souza et al. (2018), and Hildt et al. (2020), who reported the tendency of greater productivity as LV increased, in this study, an opposite behavior was detected. That is, the productivity tended to be lower with the increase of LV due to lower concentration and number of greater volume logs in the strip roads and, consequently, more time was consumed in the working cycle, as explained above.

Under the same SL and LV conditions, the effect of the extraction distance increase on the productivity and cost was more evident in the clearcutting operation (Fig. 3). At the extraction distance of $100 \mathrm{~m}$, the $P_{\mathrm{PMH}}$ was $52.2 \%$ greater in clearcutting than in first thinning, while the cost was $34.3 \%$ lower. Considering an extraction distance of $350 \mathrm{~m}$, the differences in $P_{\mathrm{PMH}}$ and cost dropped to $19.9 \%$ and $16.6 \%$, respectively. This may be related to the fact that a greater concentration and number of logs in the strip roads in clearcutting had more effect on the total time consumption in the work cycle as the extraction distance was shorter.

As the extraction distance had more effect on the forwarder performance in clearcutting, the ORD for wood extraction in this operation should be greater than in first thinning (Fig. 4). However, another aspect that influenced this difference was the cost with loss of productive area, which was greater in first thinning as the road density was higher. This resulted from the adopted management regime, which included a longer rotation and a higher average price of the standing timber, resulting in a greater revenue that would be generated in the area occupied by the roads.

Moreover, Heinimann (2017) mentions that the heavier the forest management, in terms of the volume harvested by a unit of time, the higher the expected road density (or less road spacing) is, supporting the results of this study. Such finding was also reported by Naghdi et al. (2012), who verified that, in the case of large harvested volumes, a greater number of roads tend to facilitate the road network design.

Thus, it is evident that the forest management regime and the operation type affect the dimensioning of the roads number per unit area, although there are a few studies with this approach in the literature, especially in thinning operations. Zagonel et al. (2008) reported an ORD of $27 \mathrm{~m} \mathrm{ha}^{-1}$ for clearcutting of 22-y pine plantation, which used an extraction method with a wheeled skidder. On the other hand, Souza et al. (2018), in a comparative study of operations in clearcutting of 33-y pine plantation, reported that the ORD in a cut-to-length system with forwarder was $15.63 \mathrm{~m} \mathrm{ha}^{-1}$, while this value would be $22.85 \mathrm{~m} \mathrm{ha}^{-1}$ by using a full-tree system with a wheeled skidder.

The appropriate dimensioning of road density is determinant for the operational planning process, as well as for the composition of forestry enterprises costs, since the higher the road density, the higher are the costs with construction, maintenance, and loss of productive area. Also, the environmental impacts may be higher, especially those related to water erosion (Jimenez et al. 2013), in particular when inappropriate techniques of road construction and maintenance are applied (Keller and Sherar 2010).

In many situations, such as plantations in discontinued and uneven stands due to relief restrictions or division with areas of environmental protection, the adoption of economically optimal road density may not be technically feasible (Hayati et al. 2012). Therefore, in these situations, the use of three-dimensional models or computer-assisted road network layouts is recommended, since all the transport geometry models are bidimensional (Heinimann 2017).

The use of secondary transport vehicles with a greater load capacity has been requiring better constructive standards for forest roads (Machado et al. 2013) and, due to that, it is preferable to have lower road densities, yet with higher quality. It should be noted that the optimum extraction distance and the correspondent road density will change according to the changing of machine and road costs assumptions (Spinelli et al. 2004).

In general, regardless of the forest management regime adopted, taking into account the process factors that affect the wood extraction performance is necessary to subsidize the decision-making process about the dimensioning of the forest road network. This is important to optimize the use of resources, maximize revenues, and provide sustainable forest operations.

\section{Conclusions}

The extraction distance, slope, average log volume, and type of operation had a significant effect on the specific time consumption in travels, and therefore, on 
the forwarder productivity in wood extraction. However, lower concentration and number of logs throughout the strip roads and greater difficulty in machine movement due to remaining trees reduced the productivity in first thinning compared to clearcutting.

The increase in the extraction distance gradually decreased the difference in productivity and extraction cost between the types of operation, especially in clearcutting. Thus, the secondary and tertiary optimal road density for wood extraction in this type of operation should be higher than for first thinning.

In the conditions where the study was developed, the adoption of optimal road density should allow reducing costs with construction and maintenance of the roads, as well as reduction of productive area loss, especially in first thinning. Therefore, we demonstrated that the type of operation and forest management regime, as well as the interaction with process factors, affect the sizing of the roads number per unit area, and, consequently, the forest activity costs.

\section{Acknowledgments}

The authors would like to thank Florestal Gateados without whom this study would not have been realized, the Foundation for Research Support of the Santa Catarina State (FAPESC) for the financial assistance to the research group, and reviewers for the constructive and helpful feedback.

\section{References}

Ackerman, P., Gleasure, E., Ackerman, S., Shuttleworth, B., 2014: Standards for time studies for the South African forest industry, $1^{\text {st }}$ ed.; ICFR/FESA: South Africa, 1-49 p.

Alvarez, C.A., Stape, J.L., Sentelhas, P.C., Gonçalves, J.L.M., Sparovek, G., 2014: Köppen's climate classification map for Brazil. Meteorol. Zeitschrift 22(6): 711-728. https://doi. org/10.1127/0941-2948/2013/0507

Corrêa, C.M.C., Malinovski, J.R., Roloff, G., 2006: Bases para o planejamento de rede viária em reflorestamento no Sul do Brasil (Basis for planning roadways in forest plantations in southern Brazil). Floresta 36(2): 277-286. http://dx.doi. org/10.5380/rf.v36i2.6450

Dobner Junior, M., Nutto, L., Higa, A.R., 2013: Recovery rate and quality of rotary peeled veneer from 30-year-old Pinus taeda L. logs. Ann. For. Sci. 70(4): 429-437. https://doi. org/10.1007/s13595-013-0274-z

FAO, 1974: Logging and log transport in tropical high forest; FAO: Rome, Italy, 1-89.

FAO, 1977: Planning forest roads and harvesting. FAO: Rome, Italy, 1-148.
Ghaffarian, M.R., Stampfer, K., Sessions, J., 2009: Comparison of three methods to determine optimal road spacing for forwarder-type logging operations. J. For. Sci. 55(9): 423-431.

Ghaffarian, M.R., Sessions, J., Brown, M., 2012: Machine productivity and residual harvesting residues associated with a cut-to-length harvest system in southern Tasmania. South. For. 74(4): 229-235. http://dx.doi.org/10.2989/20702620.2012 .741770

Hayati, E., Majnounian, B., Abdi, E., 2012: Qualitative evaluation and optimization of forest road network to minimize total costs and environmental impacts. Iforest 5(3): 121-125. https://doi.org/10.3832/ifor0610-009

Heinimann, H.R., 2017: Forest Road Network and Transportation Engineering - State and Perspectives. Croat. J. For. Eng. 38(2): 155-173.

Hildt, E., Leszczuk, A., Donagh, P.M., Schlichter, T., 2020: Time Consumption Analysis of Forwarder Activities in Thinning. Croat. J. For. Eng. 41(1): 13-24. https://doi. org/10.5552/crojfe.2020.615

Holzfeind, T., Stampfer, K., Holzleitner, F., 2018: Productivity, setup time and costs of a winch-assisted forwarder. J. For. Res. 23(4): 196-203. https://doi.org/10.1080/13416979.20 18.1483131

Jimenez, M.D., Ruiz-Capillas, P., Mola, I., Pérez-Corona, E., Casado, M.A., Balaguer, L., 2013: Soil development at the roadside: a case study of a novel ecosystem. Land Degrad. Dev. 24(6): 564-574. https://doi.org/10.1002/ldr.1157

Keller, G., Sherar, J., 2003: Low-volume roads engineering: best management practices field guide; USAID: Washington, USA, 1-183.

Kuitto, P.J., Keskinen, S., Lindroos, J., Oijala, T., Rajamäki, J., Räsänen, T., Terävä, J., 1994: Puutavaran Koneellinen Hakkuu Ja Metsäkuljetus (Mechanised Cutting and Forest Haulage); Metsäteollisuus: Helsinki, Finland, 1-38.

Laitila, J., Asikainen, A., Nuutinen, Y., 2007: Forwarding of whole trees after manual and mechanized felling bunching in pre-commercial thinnings. J. For. Eng. 18(2): 29-39. https:// doi.org/10.1080/14942119.2007.10702548

Leite, E.S., Fernandes, H.C., Mineti, L.J., Souza, A.P., Leite, H.G., Guedes, I.L., 2014: Modelagem do desempenho da extração de madeira pelo "forwarder" (Modeling of the performance of wood extraction made by "forwarder"). Rev. Árvore 38(5): 879-887. https://doi.org/10.1590/S010067622014000500012

Lopes, E.S., Tonhato, L., Rodrigues, C.K., Serpe, E.L. , 2016: Declividade do terreno e distância de extração na produtividade do forwarder com guincho de tração auxiliar (Slope terrain and extraction distance in productivity of forwarder with traction auxiliary winch). Nativa 4(6): 347-352. http:// dx.doi.org/10.14583/2318-7670.v04n06a01.

Magagnotti, N., Spinelli, R., 2012: Good Practice Guidelines for Biomass Production Studies; CNR IVALSA: Sesto Fiorentino, Italy; 1-52. 
Malinovski, R.A., Malinovski, R.A., Malinovski, J.R., Yamaji, F.M., 2006: Análise das Variáveis de Influência na Produtividade das Máquinas de Colheita de Madeira em Função das Características Físicas do Terreno, do Povoamento e do Planejamento Operacional Florestal (Analysis of main variables on productivity of wood harvesting machines in function of land physical and stand characteristics and forest operation planning). Floresta 36(2): 169-182. http://dx.doi. org/10.5380/rf.v36i2.6459

Manner, J., Nordfjell, T., Lindroos, O., 2013: Effects of the number of assortments and log concentration on time consumption for forwarding. Silva Fennica 47(4): 1-19. https:// doi.org/10.14214/sf.1030

Miyata, E.S., 1980: Determining fixed and operating costs of logging equipment; USDA: St. Paul, USA, 1-14.

Naghdi, R., Limaei, S.M., 2009: Optimal forest road density based on skidding and road construction costs in Iranian Caspian forests. Caspian J. Env. Sci. 7(2): 79-86.

Naghdi, R., Soleiman, M., Babapour, R., Majid, A., 2012: Designing of forest road network based on technical and economical considerations using GIS-AHP. IJANS 1(2): 39-44.

Norizah, K., Mohd-Hasmadi, I., Husna, S., Chung, W., 2016: Log hauling productivity in timber harvesting operation in peninsular malaysia forest. J. Trop. For. Sci. 28(3): 207-216.

Nurminem, T., Korpunem, H., Uusitalo, J., 2006: Time consumption analysis of the mechanized cut-to-length system. Silva Fenn. 40(2) 335-363. https://doi.org/10.14214/sf.346

Oliveira, D., Lopes, E.S., Fiedler, N.C., 2009: Avaliação técnica e econômica do Forwarder na extração de toras de pinus (Technical and economical evaluation of the Forwarder in the extraction of the pine logs). Sci. For 37(84): 525-533.

R DEVELOPMENT CORE TEAM, 2019: R: A language and environment for statistical computing. R Foundation for Statistical Computing, Vienna, Austria. URL https://www.R project.org/

Rodrigues, C.K., Lopes, E.S., Figueiredo Filho, A., Silva, M.K.C., 2018: Modeling of forwarder productivity and costs in thinned pine stands. Floresta 48(2): 285-292. https://doi. org/10.5380/rf.v48i2.56195

Ryan, T., Phillips, H., Ramsay, J., Dempsey, J., 2004: Forest Road Manual: Guidelines for the design, construction and management of forest roads. COFORD: Dublin, Ireland, $1-170$.

Scolforo, J.R.S., Maestri, R., 1997: O manejo de florestas plantadas (Management of Planted Forests). In Manejo Florestal
(Forest Management); Scolforo, J.R.S., Ed.; UFLA/FAEPE: Lavras, Brazil, 1, 313-379.

Seixas, F., Batista, J.L.F., 2014: Comparação técnica e econômica entre harvesters de pneus e com máquina base de esteiras (Technical and economical comparison between wheel harvesters and excavators). Cienc. Florest. 24(1): 185191. https://doi.org/10.5902/1980509813335.

Souza, F.L., Sampietro, J.A., Dacoregio, H.M., Soares, P.R.C., Lopes, E.S., Quadros, D.S., 2018: Densidade ótima e aceitável de estradas na colheita de pinus no sistema de toras curtas e árvores inteiras (Optimum and acceptable forest road density in pine harvesting for cut-to-length and full tree systems) Sci. For. 46(118): 189-198. https://dx.doi. org/10.18671/scifor.v46n118.05.

Spathelf, P., Seling, I., 2000: Efeitos econômicos de diferentes programas de desbaste em povoamentos de Pinus elliottii (Economic effects of different thinning programs of Pinus elliottii). Ciência Flor. 10(1): 21-44. https://doi. org/10.5902/19805098393

Spinelli, R., 2004: Harvesting of Thinnings. In Encyclopedia of Forest Sciences; Burley, J., Evans, J., Youngquist, J.A., Eds; Elsevier Academic Press: Oxford, UK, v.1; 252-259.

Stankić, I., Poršinsky, T., Tomašić, Ž., Tonković, I., Frntić M., 2012: Productivity Models for Operational Planning of Timber Forwarding in Croatia. Croat. J. For. Eng. 33(1): 61-78.

Strandgard, M., Mitchell, R., Acuna, M., 2017: Time consumption and productivity of a forwarder operating on a slope in a cut-to-length harvest system in a Pinus radiata D. Don pine plantation. J. For. Sci. 63(7): 324-330. https://doi. org/10.17221/10/2017-JFS

Szewczyk, G., Sowa, J.M., Kamiński, K., Kulak, D., Stańczykiewicz, A., 2017: Selection of time study methods for forest operations. For. Lett. 100(12): 1-12.

Toscani, P., Sekot, W., Holzleitner, F., 2020: Forest roads from the perspective of managerial accounting - empirical evidence from Austria. Forests 11(4): 378. https://doi. org/10.3390/f11040378

Walsh, D., Strandgard, M., 2014: Productivity and cost of harvesting a stemwood biomass product from integrated cut-to-length harvest operations in Australian Pinus radiata plantations. Biomass Bioenergy 66: 93-102. https://doi. org/10.1016/j.biombioe.2014.01.017

Zagonel, R., Corrêa, C.M.C., Malinovski, J.R., 2008: Densidade ótima de estradas de uso florestal em áreas de relevo plano de Pinus taeda no planalto catarinense (Optimal forest road density in plane relief in Pinus taeda forests in catarinense plateaus). Sci. For. 36(77): 33-41. 
Authors' addresses:

Prof. Jean Alberto Sampietro, $\mathrm{PhD}$ * e-mail: jean.sampietro@udesc.br Daiane A. de Vargas, BSc

e-mail: florestaldaianevargas@gmail.com Franciny L. Souza, BSc e-mail: francinylieny@hotmail.com Prof. Marcos Felipe Nicoletti, PhD e-mail: marcos.nicoletti@udesc.br Marcelo Bonazza, PhD e-mail: marcelo.bonazza@ufsc.br Larissa R. Topanotti, BSc e-mail: larissa.topanotti@ufsc.br State University of Santa Catarina Forest Engineering Department Av. Luiz de Camões, 2090 ZIP-CODE 88520 000, Lages Santa Catarina

* Corresponding author 